\title{
A new Y-shaped trace fossil attributed to upogebiid crustaceans from Early Pleistocene of Italy
}

Peter Pervesler and Alfred Uchman

Acta Palaeontologica Polonica 54 (1), 2009: 135-142 doi:http://dx.doi.org/10.4202/app.2009.0114

Y-shaped trace fossil (U-shaped upper part with a basal shaft), Parmaichnus stironensis igen. nov. et isp. nov. penetrates from a discontinuity surface cut in Early Quaternary mudstones in the Stirone Valley, Northern Italy. It is attributed to upogebiid decapod crustaceans. Parmaichnus differs from Psilonichnus by the presence of turning chambers in the upper part of the burrow. The turning chambers are considered to be an important taxonomic feature of upogebiid burrows. $P$. stironensis occurs together with Thalassinoides cf. paradoxicus (produced probably by callianassid crustaceans) and wide U-shaped pyritised cylinders (supposedly produced by balanoglossid hemichordates).

Key words: Trace fossils, Parmaichnus, Psilonichnus, crustacean burrows, Upogebia, foredeep, Pleistocene, Italy.

Peter Pervesler [peter.pervesler@univie.ac.at], Department of Palaeontology, University of Vienna, Althanstrasse 14, A-1090 Vienna, Austria; Alfred Uchman [alfred.uchman@uj.edu.pl], Institute of Geological Sciences, Jagiellonian University, ul. Oleandry 2a, PL-30-063 Kraków, Poland.

This is an open-access article distributed under the terms of the Creative Commons Attribution License (for details please see creativecommons.org), which permits unrestricted use, distribution, and reproduction in any medium, provided the original author and source are credited. 
